\title{
EFEKTIVITAS PELATIHAN GURU MELALUI PENDIDIKAN DAN LATIHAN PROFESI GURU
}

\author{
(THE EFFECTIVENESS OF TEACHER TRAINING THROUGH \\ TEACHER PROFESSIONAL EDUCATION AND TRAINING) ${ }^{1}$
}

\author{
Simon Sili Sabon \\ Peneliti Madya \\ Pusat Penelitian Kebijakan Pendidikan dan Kebudayaan \\ Jalan Jenderal Sudirman Senayan Jakarta Pusat, DKI Jakarta, Indonesia. \\ e-mail : simonsilisabon@yahoo.com \\ Naskah diterima: 26 Juni 2018; dikembalikan untuk direvisi: 27 Agustus 2018; disetujui:25 Oktober 2018
}

\begin{abstract}
Abstrak
Tujuan kajian ini adalah menganalisis efektivitas pelaksanaan program Pendidikan dan Latihan Profesi Guru apakah berhasil meningkatkan kompetensi guru, sehingga menjadi masukan bagi pembuat kebijakan dalam merancang pelatihan bagi guru di masa yang akan datang. Untuk mencapainya kajian ini akan: (i) mengidentifikasi kompetensi (pedagogik dan profesional) awal guru sebelum mengikuti program (ii) mengidentifikasi kompetensi akhir guru setelah mengikuti program, dan (iii) membandingkan kompetensi awal dan kompetensi akhir guru untuk menilai efektivitas program. Pendekatan kajian adalah kuantitatif. Data yang digunakan dalam penelitian ini adalah data sekunder tentang nilai Uji Kompetensi Guru 2012 (kompetensi awal) dan Ujian Tulis Nasional 2013 (kompetensi akhir) yang diperoleh dari Direktorat Jenderal Guru dan Tenaga Kependidikan Kementerian Pendidikan dan Kebudayaan. Data dianalisis dengan teknik statistik inferensial menggunakan uji perbedaan mean (paired sample t-test). Kajian menemukan bahwa sebelum mengikuti program, rerata nilai kompetnesi guru SD adalah 39,82 dan guru SMP adalah 52,44, sedangkan setelah mengikuti program rerata nilai kompetensi guru SD adalah 47,62 sedangkan guru SMP adalah 52,44 . Kajian menyimpulkan bahwa (i) kompetensi pedagogik dan profesional guru-guru SD dan SMP masih sangat rendah karena rerata nilai UKG 2012 dan rerata nilai UTN 2013 masih jauh di bawah standar kelulusan yang ditetapkan untuk UKG 2012 yaitu minimal 70,0 dalam skala 1-100; (ii) hasil uji statistik perbedaan rerata UTN dan UKG menunjukkan bahwa PLPG ternyata efektif dalam meningkatkan kompetensi pedagogik dan profesional guru.
\end{abstract}

Kata Kunci: Uji Kompetensi Guru, Ujian Tulis Nasional, Pendidikan Dan Latihan Profesi Guru.

\begin{abstract}
The purpose of this study is to analyze the effectiveness of the implementation of Teacher Professional Education And Training program whether the program is successful in increasing the competency of teachers, which can be an input for policy makers in designing training for teachers in the future. To achieve this purpose this study will: (i) identify the initial teacher's
\end{abstract}

1 Kajian ini merupakan bagian dari studi "Efektivitas Sertifikasi Guru" pada tahun 2014 di Puslitjakdikbud Balitbang Dikbud. 
competncies (pedagogic al and professional) before attending the program (ii) identify the final competencies of teachers after attending the program, and (iii) comparing the initial and final teacher's competencies to assess the effectiveness of program. The approach of the study is quantitative. The data used in this study is the secondary data of UKG 2012 (as initial competencies) and UTN 2013 (as final competencies) obtained from the Directorate General of Teachers and Education Personnel The Ministry of Education and Culture. Data were analyzed by using inferential statistics, using test of mean difference (paired sample t-test). The study found that before participating in the program, the average score of the competencies of elementary school teachers was 39.82 and junior high school teachers were 52.44, while after joining the program the average competency value of elementary school teachers was 47.62 while junior high school teachers were 52.44. The study concludes that: (i) the pedagogic and professional competency of teachers of elementary and junior high school is still very low because the mean value of UKG 2012, and UTN 2013 is still far below the passing grade standards set for UKG 2012 that is at least 70.0 in the scale of 1-100; (ii) Statistical test of mean difference between UTN and UKG shows that PLPG is effective in improving pedagogic and professional competency of teachers.

Keywords: Teacher Competency Test, National Written Test, Teacher Professional Education And Training.

\section{A. PENDAHULUAN}

Profesionalitas guru menjadi salah satu syarat utama dalam mewujudkan pendidikan bermutu. Pemerintah telah mengupayakan langkah-langkah strategis untuk meningkatkan profesionalitas guruguru di tanah air. Syahbani (2013) menulis pemerintah menyadari betul tentang peran guru tersebut, sampai presiden Republik Indonesia (RI) Susilo Bambang Yudhoyono pada peringatan Hari Guru Nasional XI tahun 2004 mencanangkan jabatan guru sebagai sebuah profesi. Pencanangan itu menjadi tonggak kebangkitan guru untuk senantiasa terus meningkatkan profesionalismenya. Pencanangan ini tentu akan meningkatkan status sosial guru secara signifikan sehingga membuat jabatan guru menjadi suatu profesi yang mempunyai daya tarik tersendiri bagi putra-putri terbaik negeri ini; artinya profesi guru tidak lagi hanya dilirik oleh mereka yang kepepet mencari kerja. Bahwa telah terjadi pergeseran minat lulusan SMA dengan ranking terbaik memasuki Lembaga
Pendidikan Tenaga Kependidikan (LPTK) untuk menjadi guru terbukti dari temuan studi di Pusat Penelitian Kebijakan Pendidikan dan kebudayaan (Puslitijakdikbud) pada tahun 2013, sebagaimana disajikan dalam diagram berikut.

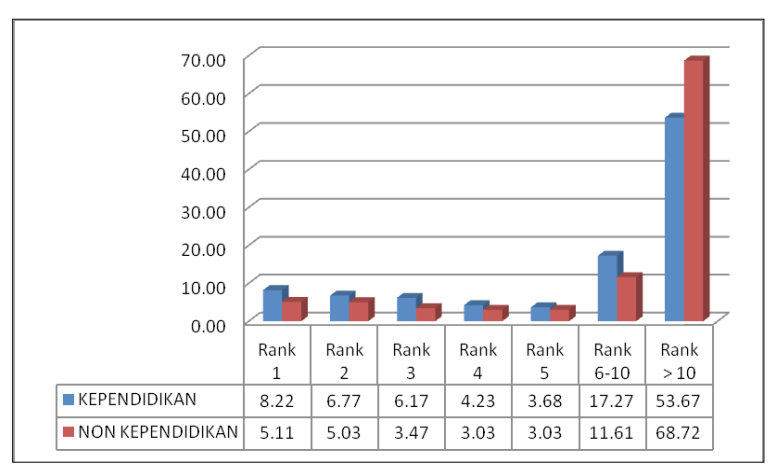

Gambar 1 Ranking Mahasiswa ketika di SMA/SMK

Dari gambar di atas terlihat jelas bahwa persentase mahasiswa program studi kependidikan yang memiliki prestasi akademik baik ketika masih di SMA lebih banyak daripada mahasiswa program studi non kependidikan. Mahasiswa program studi kependidikan saat masih duduk di bangku SMA/SMK kelas XII yang menempati 
ranking satu persentasenya lebih tinggi dibandingkan dengan mahasiswa non kependidikan. Begitu juga dengan ranking dua sampai dengan ranking lima. Sebaliknya, persentase mahasiswa yang memiliki ranking di atas 10 ketika masih duduk di bangku kelas XII lebih banyak pada pogram studi non kependidikan.

Sejak pencanangan guru sebagai sebuah profesi, semangat untuk segera menetapkan undang-undang profesi guru dan dosen berikut dengan berbagai perangkat pendukungnya, menjadi semakin kuat. Eksistensi guru tersebut kemudian dikukuhkan dalam Undang-Undang Republik Indonesia Nomor 14 Tahun 2005 tentang Guru dan Dosen. Kedudukan guru dan dosen sebagai tenaga profesional bertujuan untuk melaksanakan sistem pendidikan nasional dan mewujudkan tujuan pendidikan nasional, yaitu berkembangnya potensi peserta didik agar menjadi manusia yang beriman dan bertakwa kepada Tuhan Yang Maha Esa, berakhlak mulia, sehat, berilmu, cakap, kreatif, mandiri, serta menjadi warga negara yang demokratis dan bertanggung jawab. Kedudukan guru sebagai tenaga profesional berfungsi untuk meningkatkan martabat guru serta perannya sebagai agen pembelajaran untuk meningkatkan mutu pendidikan nasional.

Dengan terbitnya UU NO 14/2005, maka guru-guru dalam jabatan ditingkatkan kesejahteraannya yaitu akan mendapat Tunjangan Profesi Guru (TPG) minimal sebesar satu kali gaji pokoknya. Namun demikian, sebelum guru mendapat TPG, guru dalam jabatan harus memenuhi beberapa persyaratan, salah satunya adalah guru dalam jabatan harus memiliki sertifikat pendidik. Salah satu cara untuk mendapat sertifikat pendidik adalah melalui pendidikan dan pelatihan yang lebih dikenal dengan Pendidikan dan Latihan Profesi Guru (PLPG) yang diadakan oleh Lembaga Pendidik dan Tenaga Kependidikan (LPTK) yang ditunjuk oleh pemerintah. Untuk mengikuti PLPG guru juga harus memenuhi beberapa persyaratan dan salah satunya adalah sudah mengikuti Uji Kompetensi Guru (UKG).

PLPG adalah pelatihan guru untuk mendapat sertifikat pendidik. Durasi PLPG pada tahun anggaran 2013 adalah sembilan atau sepuluh hari yang diselenggarakan oleh LPTK yang ditunjuk oleh pemerintah atau dalam hal ini Kemendikbud. Setelah mengikuti PLPG guru akan mengikuti ujian akhir yang salah satu komponennya adalah Ujian Tulis Nasional (UTN). Jika guru lulus PLPG maka guru akan mendapat sertifikat pendidik. Dengan memegang sertifikat pendidik, guru tersebut sudah dianggap profesional. Setelah memiliki sertifikat pendidik, guru masih harus memenuhi beberapa persyaratan lainnya agar memperoleh kesempatan untuk mendapat TPG.

Yang menjadi pertanyaan adalah apakah dengan pelatihan yang hanya sembilan atau sepuluh hari guru-guru menjadi profesional. Pertanyaan ini perlu dikaji, karena banyak berita/isu yang beredar bahwa program pelatihan guru yang dilaksanakan pemerintah tidak cukup efektif dalam meningkatan kualitas guru, sebagaimana yang disampaikan oleh Jalmo dan Rustaman (2010) bahwa di Indonesia, peningkatan profesionalitas guru yang dilakukan melalui berbagai pelatihan hasilnya belum optimal, bahkan banyak pelatihan dapat dinilai gagal dalam meningkatkan kinerja guru di kelas. 
Dikatakannya bahwa pelatihan guru yang selama ini dilaksanakan melalui berbagai proyek peningkatan mutu pendidikan banyak yang tidak efektif, karena banyak pelatihan dilaksanakan hanya sekedar untuk memenuhi tuntutan proyek. Dengan demikian maka dirumuskan pertanyaan penelitian dari kajian ini sebagai berikut: "Apakah PLPG yang dilaksanakan pemerintah bagi guru dalam jabatan telah dapat meningkatkan kompetensi guru?"

\section{Tujuan}

Sesuai dengan pertanyaan penelitian dari kajian ini maka tujuan kajian ini adalah menganalisis efektivitas pelaksanaan PLPG apakah PLPG dapat berhasil meningkatkan kompetensi guru yang dapat menjadi masukan bagi pembuat kebijakan dalam merancang pelatihan bagi guru di masa yang akan datang. Dari tujuan umum tersebut dirumuskan tujuan khusus yaitu: 1) mengidentifikasi kompetensi awal guru sebelum mengikuti PLPG berdasarkan satuan pendidikan dan mata pelajaran yang diajarkan guru; 2) mengidentifikasi kompetensi akhir guru setelah mengikuti PLPG berdasarkan satuan pendidikan dan mata pelajaran yang diajarkan guru; dan 3) membandingkan kompetensi awal guru sebelum mengikuti PLPG dan kompetensi akhir guru setelah mengikuti PLPG berdasarkan satuan pendidikan dan mata pelajaran yang diajarkan guru.

\section{Hipotesis}

Hipotesis awal dari kajian ini yaitu kompetensi guru meningkat setelah mengikuti PLPG atau dengan kata lain kompetensi guru setelah mengikuti PLPG lebih tinggi daripada sebelum mengikuti PLPG.

\section{Manfaat kajian}

Kajian ini memberikan manfaat bagi Pemerintah Pusat dan Daerah serta bagi guru sebagai objek yang diteliti. Bagi Pemerintah Pusat dan Daerah: Direktorat Jenderal (Ditjen) Guru dan Tenaga Kependidikan (GTK) dan Dinas Pendidikan Provinsi dan Kabupaten/Kota: instansi pemerintah terkait ini akan mendapat masukan tentang efektivitas pelaksanaan pelatihan yang dapat menjadi masukan dalam merancang pelatihan yang lebih efektif; sedangkan bagi guru: guru akan merasa tertantang untuk lebih serius lagi dalam mengikuti program pelatihan apabila hasil kajian menunjukkan bahwa guru tidak mengalami peningkatan kompetensi setelah mengikuti PLPG.

\section{Guru sebagai Profesi}

Suharso (2013) menyampaikan bahwa guru adalah suatu profesi yang sedang tumbuh. Usaha profesionalisasi merupakan hal yang tidak perlu ditawar-tawar lagi karena uniknya profesi guru. Profesi guru harus memiliki berbagai kompetensi dan minimal empat kompetensi yaitu profesional, pedagogik, kepribadian dan sosial. Seorang guru dianggap profesional apabila mampu mengerjakan tugasnya dengan selalu berpegang teguh pada etika kerja, independent (bebas dari tekanan pihak luar), cepat (produktif), tepat (efektif), efisien dan inovatif serta didasarkan pada prinsip-prinsip pelayanan prima yang didasarkan pada unsur-unsur ilmu atau teori yang sistematis, kewenangan profesional, pengakuan masyarakat dan kode etik yang regulatif. Pengembangan wawasan dapat dilakukan melalui forum pertemuan profesi, pelatihan ataupun upaya pengembangan dan belajar secara mandiri. 
Sejalan dengan hal tersebut, Suharso (2013) menyampaikan bahwa seorang guru harus terus meningkatkan profesionalitasnya melalui berbagai kegiatan yang dapat mengembangkan kemampuannya dalam mengelola pembelajaran maupun kemampuan lain dalam upaya menjadikan peserta didik memiliki keterampilan belajar, mencakup keterampilan dalam memperoleh pengetahuan (learning to know), keterampilan dalam pengembangan jati diri (learning to be), keterampilan dalam pelaksanaan tugas-tugas tertentu (learning to do), dan keterampilan untuk dapat hidup berdampingan dengan sesama secara harmonis (learning to live together).

\section{Cara-cara Peningkatan Kompetensi/ Profesionalitas Guru}

Berangkat dari makna dan syarat-syarat profesi sebagaimana dijelaskan Suharso (2013) pada bagian terdahulu, maka dalam rangka pengembangan profesionalitas guru secara berkelanjutan dapat dilakukan dengan berbagai strategi antara lain: (i) berpartisipasi di dalam pelatihan atau in service training yaitu bentuk pelatihan yang fokusnya adalah keterampilan tertentu yang dibutuhkan oleh guru untuk melaksanakan tugasnya secara efektif. Pelatihan ini cocok dilaksanakan pada salah satu bentuk pelatihan preservice atau in-service. Model pelatihan ini berbeda dengan pendekatan pelatihan yang konvensional, karena penekanannya lebih kepada evaluasi performance nyata suatu kompetensi tertentu dari peserta pelatihan; (ii) membaca dan menulis jurnal atau makalah ilmiah lainnya. Dengan membaca dan memahami banyak jurnal atau makalah ilmiah lainnya dalam bidang pendidikan yang terkait dengan profesi guru, maka guru dengan sendirinya dapat mengembangkan profesionalisme dirinya; (iii) berpartisipasi di dalam kegiatan pertemuan ilmiah. Pertemuan ilmiah memberikan makna penting untuk menjaga kemutakhiran (up to date) hal-hal yang berkaitan dengan profesi guru. Tujuan utama dari kegiatan pertemuan ilmiah adalah menyajikan berbagai informasi dan inovasi terbaru di dalam suatu bidang tertentu; (iv) melakukan penelitian seperti Penelitian Tindakan Kelas (PTK) yang merupakan studi sistematik yang dilakukan guru melalui kerja sama atau tidak dengan guru lain dalam rangka merefleksikan dan sekaligus meningkatkan praktik pembelajaran secara terus-menerus juga merupakan strategi yang tepat untuk meningkatkan profesionalitas guru; (v) partisipasi di dalam organisasi/ komunitas profesional. Ikut serta menjadi anggota organisasi profesional juga akan meningkatkan profesionalitas seorang guru. Organisasiprofesional biasanyaakanmelayani anggotanya untuk selalu mengembangkan dan memelihara profesionalitasnya dengan membangun hubungan erat dengan masyarakat. Dalam hal ini yang terpenting adalah guru harus pandai memilih suatu bentuk organisasi profesional yang dapat memberi manfaat utuh bagi dirinya melalui bentuk investasi waktu dan tenaga; (vi) kerja sama dengan tenaga profesional lainnya di sekolah. Seseorang cenderung untuk berpikir dari pada keluar untuk memperoleh pertolongan atau informasi mutakhir akan lebih mudah jika berkomunikasi dengan orang-orang di dalam tempat kerja yang sama (termasuk belajar dari rekan atau teman sejawat). Pertemuan secara formal maupun informal untuk mendiskusikan berbagai isu 
atau permasalahan pendidikan termasuk bekerja sama dalam berbagai kegiatan misalnya merencanakan, melaksanakan, dan mengevaluasi program-program sekolah dengan kepala sekolah, orangtua peserta didik (komite sekolah), guru dan staf lain yang profesional dapat menolong guru dalam memutakhirkan pengetahuannnya.

Dalamkajianiniguruyang menjadi sasaran kajian adalah guru dalam jabatan yaitu guru yang sudah bekerja beberapa tahun, dengan demikian semua strategi untuk meningkatkan profesionalitas guru yang disebutkan di atas ini tepat. Namun demikian dalam kajian ini strategi peningkatan profesionalitas guru yang hendak dikaji adalah strategi pertama yaitu in service training. Namun demikian pelatihan ini difokuskan untuk meningkatkan dua kompetensi guru saja yaitu khusus kompetensi profesional dan pedagogik yang merupakan kompetensi yang dites secara tertulis pada akhir pelaksanaan PLPG.

\section{Hakekat Pendidikan dan Pelatihan (Diklat)}

Rezita (2015) mendefenisikan pendidikan dan pelatihan sebagai serangkaian kegiatan yang mengutamakan pengetahuan, keterampilan dan peningkatan sikap seseorang pegawai dalam melaksanakan tugasnya dalam rangka pencapaian tujuan organisasi yang efektif dan efisien. Pengetahuan, keterampilan dan kemampuan yang memadai akan memudahkan pegawai dalam menyelesaikan pekerjaannya. Jadi, pendidikan dan pelatihan merupakan salah satu cara pengembangan sumber daya manusia untuk meningkatkan kemampuan pegawai dalam menangani berbagai jenis tugas dan menerapkan kemampuan yang dibutuhkan sesuai dengan jenis pekerjaan yang ada, sehingga pegawai dapat mengerjakan pekerjaannya secara optimal. Disebutkan bahwa tujuan pendidikan dan pelatihan yaitu untuk meningkatkan pengetahuan, kemampuan, dan keterampilan pegawai agar lebih profesional dalam menjalankan pekerjaannya sehingga tujuan organisasi dapat tercapai dan memiliki keterkaitan dengan kinerja pegawai.

Lebih lanjut Rezita (2015) menyampaikan bahwa hampir seluruh organisasi baik pemerintah maupun swasta menyadari akan keterbatasannya dalam menghadapi berbagai perubahan. Perubahan yang datang dalam menjawab tantangan baik yang berasal dari diri sendiri, maupun perubahan yang datang dari luar seperti perubahan kebutuhan masyarakat akan teknologi baru. Untuk menghadapi dan menjawab perubahan tersebut bisa dilakukan dengan berbagai cara, salah satunya adalah dengan melakukan program pendidikan dan pelatihan. Pendidikan dan pelatihan (Diklat) dapat dipandang sebagai salah satu bentuk investasi. Oleh karena itu, setiap organisasi harus memperhatikan pendidikan dan pelatihan bagi pegawainya. Jadi, penyelenggaraan program pendidikan dan pelatihan sangatlah penting bagi pegawai baik untuk masa sekarang ataupun masa yang akan datang, karena dengan adanya pendidikan dan pelatihan kemampuan, pengetahuan, keterampilan, sikap serta produktivitas pegawai akan meningkat.

Untuk itu Rezita (2015) menyarankan agar pengembangan kualitas dan kemampuan sumber daya manusia harus melalui suatu proses perencanaan pendidikan, pelatihan, dan pengelolaan tenaga atau pegawai untuk mencapai suatu hasil optimal. Pegawai sebaiknya diberikan penambahan pengetahuan dengan terlebih dahulu 
mengkaji atau melakukan analisis kebutuhan. Analisis kebutuhan ini bertujuan untuk mengetahui bagaimana kemampuan mereka (pegawai) saat ini dan apa yang seharusnya perlu dikuasai dan diketahui oleh pegawai dalam hubungannya dengan tugas dan tanggung jawab mereka. Walaupun demikian, penambahan pengetahuan belum cukup untuk dapat mengantarkan seorang pegawai bekerja secara profesional.

Menurut Detty (2008) pelatihan merupakan suatu kebutuhan yang esensial bagi kelangsungan hidup sebuah perusahaan. Beberapa alasan yang mendasari hal ini adalah adanya pandangan yang menyatakan bahwa pelatihan dapat meningkatkan nilai tambah bagi seseorang dan bukan hanya menjadi suatu tujuan untuk mempengaruhi kinerja jangka pendek. Selain itu, masyarakat di beberapa negara, termasuk di Indonesia, berpandangan bahwa terdapat hubungan antara pelatihan dengan pendidikan. Perusahaan juga sering memilih pelatihan sebagai salah satu strategi untuk mengembangkan karyawannya dalam rangka mencapai tujuan organisasi, sehingga tidaklah mengherankan jika banyak perusahaan yang sudah mulai menyiapkan anggaran yang cukup besar untuk program pelatihan dan pengembangan karyawannya. Sayangnya, investasi yang besar untuk program pelatihan terkadang tidak diikuti dengan efektivitas dari evaluasi pelatihannya itu sendiri.

\section{Manfaat Diklat Guru}

Guru merupakan sumber daya manusia di bidang pendidikan. Rustiana (2010) mengungkapkan bahwa sumber daya manusia mempunyai peran penting yang dapat mempengaruhi keberhasilan suatu organisasi dalam rangka mencapai tujuannya. Sumber daya manusia dan kualitasnya merupakan isu yang sangat strategis karena kualitas manusia akan mendukung keberhasilan dalam melaksanakan pekerjaan. Oleh karena itu peningkatan kemampuan sumber daya manusia baik dari aspek pengetahuan maupun aspek ketrampilan perlu dilakukan secara terus menerus. Latihan-latihan yang diberikan kepada para karyawan akan mendorong karyawan untuk bekerja lebih keras. Hal ini disebabkan karena karyawan-karyawan yang telah mengetahui dengan baik tugas-tugas dan tanggung-jawabnya akan mencapai tingkat moral kerja yang lebih tinggi. Berdasarkan uraian ini Rustiana (2010) berpendapat bahwa pelatihan merupakan proses membantu para tenaga kerja untuk memperoleh efektivitas dalam pekerjaan mereka yang sekarang atau yang akan datang melalui pengembangan kebiasaan tentang pikiran dan tindakan, kecakapan, pengetahuan, dan sikap yang layak. Sejalan dengan Rustiana, Rezita (2015) menyampaikan manfaat pendidikan dan pelatihan adalah untuk meningkatkan stabilitas pegawai dan dapat memberikan kesempatan bagi pegawai untuk mengembangkan diri agar dalam melaksanakan tugas dapat berjalan dengan efektif dan efisien.

\section{Hakekat PLPG dan UKG sebagai Persya- ratan Mengikuti PLPG}

PLPG merupakan salah satu dari beberapa cara bagi guru dalam jabatan untuk mendapat sertifikat pendidik. Sertifikat tersebut merupakan salah satu persyaratan untuk mendapat TPG. Bahwa PLPG merupakan salah satu cara guru untuk mendapat sertifikat pendidik dapat dilihat dalam kerangka berikut. 


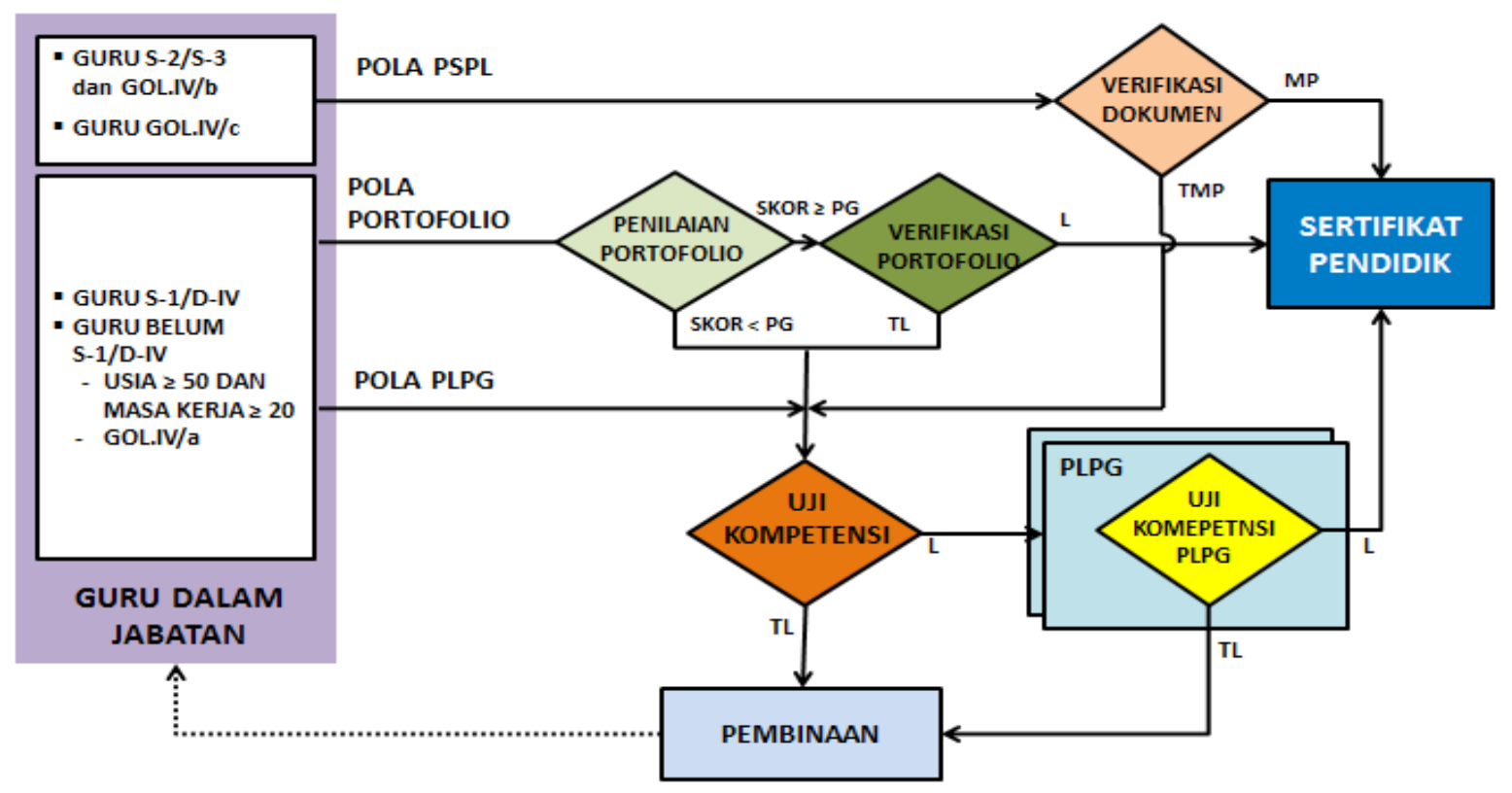

Sumber: Konsorsium Sertifikasi Guru (KSG) Ditjen GTK Kemendikbud (2013)

Gambar 2. Alur Sertifikasi bagi Guru dalam Jabatan

Dalam kerangka di atas terlihat ada tiga cara bagi guru dalam jabatan untuk memperoleh sertifikat pendidik. Berikut disajikan uraian tentang ketiga pola sertifikasi bagi guru dalam jabatan untuk mendapat sertifikat pendidik sebagaimana yang tertera dalam panduan Pelaksanaan PLPG yang disusun KSG Ditjen GTK Kemendikbud (2013): (I) Pola Pemberian Sertifikat Pendidik secara Langsung (Pola PSPL): sertifikasi guru pola PSPL diperuntukkan bagi guru dalam jabatan yang memenuhi persyaratan berikut: (i) guru mata pelajaran atau guru kelas atau guru bimbingan dan konseling yang sudah memiliki kualifikasi akademik S-2 atau S-3 dari perguruan tinggi terakreditasi dalam bidang kependidikan atau bidang studi yang relevan dengan mata pelajaran atau rumpun mata pelajaran yang diampunya dengan golongan paling rendah IV/b atau yang memenuhi angka kredit kumulatif setara dengan golongan IV/b; (ii) guru yang diangkat dalam jabatan pengawas pada satuan pendidikan yang sudah memiliki kualifikasi akademik S-2 atau S-3 dari perguruan tinggi terakreditasi dalam bidang kependidikan atau bidang studi yang relevan dengan tugas kepengawasan dengan golongan paling rendah $\mathrm{IV} / \mathrm{b}$ atau yang memenuhi angka kredit kumulatif setara dengan golongan IV/b; dan (iii) guru yang sudah mempunyai golongan paling rendah IV/c, atau yang memenuhi angka kredit kumulatif setara dengan golongan IV/c (melalui in passing); (II) Pola Penilaian Portofolio (Pola PF): peserta sertifikasi pola $\mathrm{PF}$ adalah guru dan guru yang diangkat dalam jabatan pengawas satuan pendidikan yang telah memenuhi persyaratan akademik dan administrasi serta memiliki prestasi dan kesiapan diri. Sementara itu, bagi guru yang telah memenuhi persyaratan akademik dan administrasi, namun tidak memiliki kesiapan diri untuk mengikuti sertifikasi melalui pola PF, dibolehkan mengikuti sertifikasi dengan pola PLPG setelah lulus Uji Kompetensi 
Guru (UKG); (III) Pendidikan dan Latihan Profesi Guru (PLPG): PLPG merupakan pola sertifikasi guru dalam bentuk pelatihan yang diselenggarakan oleh rayon Lembaga Pendidikan Tenaga Kependidikan (LPTK) untuk memfasilitasi terpenuhinya standar kompetensi guru peserta sertifikasi. Beban belajar PLPG sebanyak 90 jam pembelajaran selama sembilan atau sepuluh hari dan dilaksanakan dalam bentuk perkuliahan dan workshop menggunakan pendekatan Pembelajaran Aktif, Inovatif, Kreatif, Efektif, dan Menyenangkan (PAIKEM). Perkuliahan dilaksanakan untuk penguatan materi bidang studi, model-model pembelajaran, dan karya ilmiah. Workshop dilaksanakan untuk mengembangkan, mengemas perangkat pembelajaran dan penulisan karya ilmiah. Pada akhir PLPG dilaksanakan uji kompetensi.

Peserta sertifikasi pola PLPG adalah guru yang bertugas sebagai guru kelas, guru mata pelajaran, guru bimbingan dan konseling atau konselor, serta guru yang diangkat dalam jabatan pengawas satuan pendidikan yang memilih: (i) sertifikasi pola PLPG, (ii) pola PF yang berstatus tidak mencapai passing grade penilaian portofolio atau Tidak Lulus Verifikasi Porto Folio (TLVPF), dan (iii) PSPL tetapi berstatus Tidak Memenuhi Persyaratan (TMP) yang lulus UKG. Bagi guru yang diangkat dalam jabatan pengawas pelaksanaan PLPG mengikuti mata pelajaran bidang keahliannya atau latar belakang pendidikan S1-nya.

Sertifikasi guru Pola PSPL, PF, dan PLPG dilakukan oleh rayon LPTK penyelenggara sertifikasi guru yang memperoleh penugasan dari Menteri Pendidikan dan Kebudayaan. Rayon LPTK penyelenggara terdiri atas LPTK induk dan LPTK mitra. Bagi rayon LPTK yang ditugasi oleh KSG untuk mensertifikasi mata pelajaran khusus dapat didukung oleh perguruan tinggi yang memiliki program studi yang relevan dengan mata pelajaran yang disertifikasi. Penyelenggaraan sertifikasi guru dikoordinasikan oleh KSG.

Dalam panduan pelaksanaan PLPG (KSG Ditjen GTK Kemendikbud, 2013) disebutkan kriteria kelulusan PLPG sebagai berikut. Peserta Ujian Tulis Nasional (UTN) harus mencapai nilai Skor Akhir Kelulusan (SAK) minimal 65 (SAK $\geq 65$ ). Skor Akhir Kelulusan sendiri terdiri atas komponenkomponen yang tertera dalam rumus berikut: $\mathrm{SAK}=0,25 \mathrm{SUT}+0,30 \mathrm{SUP}+0,25 \mathrm{HW}+$ $0,1 \mathrm{SP}+0,1 \mathrm{SS}$. Keterangan: $\mathrm{SAK}=$ Skor Akhir Kelulusan PLPG, SUT $=$ Skor Ujian Tulis (Skor maksimal 100), SUP = Skor Ujian Praktik pembelajaran (skor maksimal 100), HW = skor Hasil Workshop (skor maksimal 100)*), SP = Skor Partisipasi dalam teori dan praktik pembelajaran (skor maksimal 100), dan SS = Skor teman Sejawat (skor maksimal 100). Selain itu untuk lulus masih ada nilai minimal untuk beberapa komponen SAK sebagai berikut: (i) Skor Ujian Tulis Nasional $($ SUTN) $\geq 42$; (ii) Skor Ujian Tulis (SUT) $\geq$ $60 ;($ SUT $=0,4$ SUTN $+0,6$ SUTL; SUTL $=$ Skor Ujian Tulis LPTK) dan (iii) Skor Ujian Praktik (SUP) $\geq 65$.

Dalam panduan pelaksanaan PLPG (KSG GTK Kemendikbud, 2013) disebutkan pula bahwa untuk dapat mengikuti PLPG guru harus memenuhi beberapa persyaratan dan salah satunya adalah sudah mengikuti Uji Kompetensi Guru (UKG). Undang-Undang Nomor 14 Tahun 2005 tentang Guru dan Dosen mendefinisikan bahwa profesional adalah pekerjaan atau kegiatan yang 
dilakukan oleh seseorang dan menjadi sumber penghasilan kehidupan yang memerlukan keahlian, kemahiran, atau kecakapan yang memenuhi standar mutu atau norma tertentu serta memerlukan pendidikan profesi. Jadi dengan terbitnya UUGD, kesejahteraan guru ditingkatkan asalkan guru harus memenuhi persyaratan yang ditetapkan dalam UUGD. Persyaratan utama untuk dapat menerima TPG adalah memiliki sertifikat pendidik, dan salah satu cara untuk mendapat sertifikat pendidik adalah melalui PLPG sebagaimana diuaraikan di atas.

Gunarto (2013) dan Martaningsih (2012) menguraikan bahwa Uji Kompetensi Guru (UKG) dimaksudkan untuk mengetahui peta penguasaan guru pada kompetensi pedagogik dan kompetensi profesional. Peta penguasaan kompetensi guru tersebut akan digunakan sebagai dasar pertimbangan dalam pemberian program pembinaan dan pengembangan profesi guru. Output UKG difokuskan pada identifikasi kelemahan guru dalam penguasaan kompetensi pedagogik dan profesional. Jadi, UKG merupakan ujian bagi guru Republik Indonesia yang dilaksanakan melalui on line maupun tertulis, dan sifatnya wajib diikuti semua guru. UKG juga dilakukan untuk pemetaan kompetensi, Pengembangan Keprofesian Berkelanjutan (PKB) dan sebagai entry point Penilaian Kinerja Guru (PKG). Gunarto (2013) kemudian menyampaikan bahwa UKG memiliki tiga tujuan sebagai berikut: (i) pemetaan penguasaan kompetensi guru (kompetensi pedagogik dan profesional) sebagai dasar pertimbangan pelaksanaan program pembinaan dan pengembangan profesi guru dalam bentuk kegiatan pengembangan keprofesian berkelanjutan, (ii) sebagai entry point penilaian kinerja guru dan sebagai alat kontrol pelaksanaan penilaian kinerja guru, dan (iii) program pengembangan keprofesian berkelanjutan dan penilaian kinerja guru wajib dilakukan setiap tahunnya sebagai persyaratan untuk kenaikan pangkat dan jabatan fungsional guru.

Uji Kompetensi Guru (UKG) diselenggarakan oleh Kementerian Pendidikan dan Kebudayaan Republik Indonesia, dilaksanakan secara nasional dengan tujuan untuk memetakan kompetensi guru (pedagogik maupun profesional) sebagai dasar pelaksanaan dan pengembangan profesi guru. Untuk meningkatkan efektivitas dan efisiensi pembinaan profesi memang diperlukan suatu pemetaan kompetensi yang secara detail bisa mendeskripsikan kondisi objektif kompetensi, materi serta strategi pembinaan yang dibutuhkan oleh guru. Peta tersebut hanya dapat diperoleh melalui uji kompetensi guru. UKG menjadi entry point penilaian kinerja guru dan sebagai alat kontrol pelaksanaan Penilaian Kinerja Guru. UKG wajib diikuti oleh semua guru baik PNS maupun Guru Tetap Yayasan. Berdasarkan panduan pelaksanaan PLPG (KSG GTK Kemendikbud, 2013), UKG tahun 2012 secara teknis dapat diuraikan sebagai berikut: (i) dilaksanakan secara on line atau tertulis di lokasi yang sudah ditunjuk; (ii) bentuk soal tesnya obyektif jenis pilihan ganda dengan 4 opsi pilihan jawaban; (iii) komposisi tes terdiri dari 30 persen kompetensi pedagogik dan 70 persen kompetensi profesional; (iv) waktu pengerjaan soal ujian 120 menit; dan (v) jumlah soal maksimal 100 butir soal. UKG tahun 2012 dilaksanakan dengan menggunakan dua sistem yakni paper-pencil-test dan sistem ujian online. Sistem paper-pencil-test merupakan sistem 
manual yang dilaksanakan pada daerah yang tidak terjangkau jaringan internet dan tidak memiliki laboratorium komputer yang terhubung dalam jaringan intranet. Sedangkan sistem ujian online dilaksanakan pada daerah yang terjangkau internet yang memadai.

\section{Pengukuran Efektivitas Pendidikan dan Pelatihan}

Meitaningrum dkk. (2013) mengutip dari buku Managemen Sumber Daya Manusia karangan Gomes yang menyampaikan bahwa terdapat lima tingkatan dalam mengukur efektivitas suatu program pendidikan dan pelatihan yaitu: (i) reactions, yaitu melalui opini peserta Diklat terhadap program pelatihan, dengan menggunakan kuesioner. Pada akhir pelatihan para peserta ditanya mengenai seberapa jauh tingkat kepuasan mereka terhadap pelatihan secara keseluruhan, terhadap pelatih/instruktur, materi yang disampaikan, isinya, bahanbahan yang disediakan, dan lingkungan pelatihan (ruangan, waktu istirahat, makanan, suhu udara), (ii) learning, yaitu untuk mengetahui seberapa jauh para peserta menguasai kensep-konsep, pengetahuan dan keterampilan-keterampilan yang diberikan selama pelatihan. Biasanya dilakukan dengan mengadakan test tertulis (essay atau multiple choice), performance test dan latihan-latihan simulasi, (iii) behaviors, yaitu menilai/membandingkan performance dari para peserta sebelum dan sesudah pelatihan, guna mengetahui tingkat pengaruh pelatihan terhadap perubahan performance mereka, (iv) organizational result, yaitu untuk menguji dampak pelatihan terhadap kelompok kerja atau organisasi secara keseluruhan. Data bisa dikumpulkan sebelum dan sesudah pelatihan atas dasar kriteria produktivitas, pergantian, absen, kecelakaan-kecelakaan, keluhankeluhan, perbaikan kualitas, kepuasan klien dan sejenis lainnya, (v) cost effectivity, dimaksudkan untuk mengetahui besarnya biaya yang dihabiskan bagi program pelatihan, dan apakah besarnya biaya untuk pelatihan tersebut terhitung kecil atau besar dibandingkan biaya yang timbul dari permasalahan yang dialami oleh organisasi.

Dalam kajian ini, efektivitas Diklat lebih cenderung menggunakan tingkatan nomor yang ketiga yaitu tingkatan behaviours yaitu membandingkan performance peserta sebelum dan sesudah mengikuti Diklat. Jika ada peningkatan performance peserta maka Diklat dikatakan atau dianggap efektif.

Selain itu dalam kajian ini efektivitas PLPG juga diukur dengan menggunakan Penilaian Acuan Patokan (PAP) atau Criterion Referenced Evaluation sebagaimana yang ditetapkan dalam panduan pelaksanaan PLPG (KSG GTK Kemendikbud, 2013) yaitu bahwa kelulusan peserta PLPG ditetapkan dengan ketentuan penilaian menggunakan acuan kriteria atau yang dikenal dengan PAP. Ermawati dkk. (2012) menyebutkan bahwa dalam menentukan kelulusan terhadap suatu tes atau ujian, terdapat dua jenis penilaian yaitu Penilaian Acuan Patokan (PAP) dan Penilaian Acuan Norma (PAN). PAP didefinisikan sebagai penilaian yang sesuai dengan target yang tergantung pada tujuan belajar awal yang sudah dipatok, sedangkan PAN didefinisikan sebagai penilaian dengan target norma yang tergantung pada kelompok.

Berdasarkan panduan pelaksanaan PLPG (KSG GTK Kemendikbud, 2013) untuk lulus PLPG, patokan Skor Akhir Kelulusan (SAK) adalah harus lebih besar atau sama dengan 65 
$(\mathrm{SAK} \geq 65)$. Skor Akhir Kelulusan sendiri terdiri atas beberapa komponen dan salah satunya adalah Skor Ujian Tulis Nasional (SUTN). Patokan kelulusan untuk Skor Ujian Tulis Nasional ditetapkan harus lebih besar atau sama dengan 42 (SUTN $\geq 42$ ). Dengan demikian, berdasarkan patokan ini akan dilakukan penilaian terhadap efektivitas pelatihan guru melalui PLPG.

\section{Beberapa hasil kajian terdahulu yang relevan antara lain sebagai berikut.}

Chairiah (2010) dalam studi kasusnya di SMP Muhammadiyah 22 Setiabudi Pamulang Tangerang Banten, tentang "Efektivitas PLPG Dalam Menunjang Profesionalisme Guru" dengan mewawancara 10 orang guru yang telah mengikuti PLPG dan menyebar angket kepada 22 orang guru; hasil penelitiannya menunjukkan bahwa peran PLPG cukup efektif dalam menunjang profesionalisme guru. Simpulan ini didasarkan pada data bahwa setelah mengikuti PLPG guruguru memperoleh tambahan wawasan, pengetahuan, dan pengalaman yang dapat digunakannya dalam melaksanakan KBM. Dikatakan bahwa guru-guru menjadi lebih termotivasi untuk mengajar karena dapat menerapkan model-model pembelajaran yang diperolehnya saat mengikuti PLPG. Selain itu guru-guru juga dapat mendiseminasikan informasi atau pengalamannya kepada rekan sejawatnya untuk bersama-sama mencari formulasi menyelesaikan persoalan KBM dan juga dalam merencanakan proses pembelajaran di kelas.

Listiyani (2014) dalam studi kasusnya tentang "KontribusiPelatihanDanPengalaman Mengajar Terhadap Profesionalisme Guru Sekolah Dasar Negeri Di Kecamatan Semin 170
Kabupaten Gunungkidul DIY" dengan jumlah sampel sebanyak 131 guru; hasil kajiannya sama dengan hasil kajian Chairiah (2010) karena hasil analisis datanya menunjukkan bahwa terdapat kontribusi yang positif dan signifikan antara pelatihan guru terhadap profesionalisme guru, artinya pelatihan guru berpengaruh terhadap peningkatan profesionalisme guru. Studi kasus Kornelius dkk. (2014) juga menunjukkan hasil yang serupa. Dalam kajian mereka dengan judul "Pendidikan Dan Pelatihan Guru Dalam Meningkatkan Kualitas Pendidikan Di SMP Negeri 27 Sendawar Kabupaten Kutai Barat Kalimantan Timur"; hasil kajiannya menunjukkan bahwa pendidikan dan pelatihan guru yang dilakukan SMP Negeri 27 Sendawar Kabupaten Kutai Barat, mampu meningkatkan keterampilan dan keahlian para guru di sekolah tersebut. Hal tersebut dapat diketahui dari jumlah guru yang memiliki legalitas pelatihan sesuai mata pelajaran yang diampu. Hal ini terindikasi oleh berbagai legalitas pelatihan yang dimiliki guru antara lain pelatihan manajemen sekolah, pelatihan pembinaan kesiswaan, pelatihan karya tulis ilmiah, pelatihan teknis berbasis kompetensi, maupun dalam bentuk penataran lainnya. Dikatakan bahwa manfaat yang dirasakan bukan hanya untuk meningkatkan pengetahuan, keterampilan dan keahlian, tetapi dapat menambah wawasan berpikir para guru dalam menghadapi proses belajar mengajar. Di samping itu dengan diberikan pendidikan dan pelatihan, guru-guru terpacu semangat kerjanya dalam meningkatan kualitas pendidikan. Hal tersebut dapat dilihat dari dua aspek: yaitu, (i) kecakapan dan pengetahuan tentang pekerjaan; serta (ii) tingkat kematangan berpikir dalam 
menghadapi pekerjaan dan kejiwaan.

Hasil kajian Lathifah (2013) sedikit berbeda dengan hasil tiga kajian di atas. Dalam studi kasusnya tentang "Pengaruh PLPG Terhadap Peningkatan Profesionalisme Guru PKn Di Kota Bandung Jawa Barat" dengan besar sampelnya 30 guru; hasil penelitiannya juga menunjukkan bahwa PLPG berpengaruh signifikan terhadap peningkatan kompetensi secara keseluruhan karena kekuatan korelasinya sebesar 0,581, namun ketika dilakukan analisis per aspek kompetensi, hasil analisisnya menunjukkan bahwa PLPG tidak berpengaruh pada peningkatan kompetensi pedagogik karena kekuatan korelasinya hanya sebesar 0,111, PLPG tidak berpengaruh signifikan terhadap peningkatan kompetensi kepribadian karena kekuatan korelasinya hanya sebesar 0,111 , PLPG tidak berpengaruh signifikan terhadap peningkatan kompetensi sosial karena kekuatan korelasinya 0,000 dan PLPG juga tidak berpengaruh signifikan terhadap peningkatan kompetensi profesional karena kekuatan korelasinya hanya sebesar 0,025. Hasil kajian Syarif Hidayat (2015) hampir serupa dengan hasil kajian Lathifah (2013). Dalam studi kasusnya tentang "Pengaruh PLPG Dalam Menunjang Profesionalisme Guru IPS" dengan jumlah sampelnya sama dengan jumlah populasi yaitu sebanyak 27 guru IPS se-Kecamatan Sawangan Depok Jawa Barat; ditemukan bahwa PLPG cukup berpengaruh pada peningkatan profesionalisme guru. Hal ini dapat dilihat dari kenyataan bahwa setelah mengikuti PLPG, guru mendapatkan pengetahuan dan pengalaman tentang kegiatan belajar mengajar yang dapat memotivasi guru untuk menerapkan model-model pembelajaran yang diperolehnya sehingga pembelajaran di kelas tidak berjalan membosankan dan juga membantu guru dalam merencanakan proses pembelajaran. Namun demikian, hasil analisisnya per aspek kompetensi yaitu profesional, padagogik, sosial dan kepribadian menunjukkan bahwa PLPG kurang dapat meningkatkan kompetensi tersebut. Hal ini ditengarai disebabkan karena kurang adanya pengawasan dan pembinaan berkelanjutan dari masing-masing sekolah setelah guru mengikuti PLPG.

Dari lima hasil kajian di atas meskipun hasilnya tidak persis sama namun tetap dapat disimpulkan bahwa pendidikan dan pelatihan guru berpengaruh positif pada peningkatan profesionalisme guru. Simpulan ini diambil karena meskipun hasil dari dua kajian yang terakhir berbeda dengan hasil dari tiga kajian yang diuraikan sebelumnya namun sesungguhnya hasilnya masih sejalan, yaitu pendidikan dan pelatihan terbukti dapat meningkatkan profesionalisme guru. Yang membedakan adalah bahwa ketika analisis dilakukan per aspek kompetensi, maka pengaruh pendidikan dan pelatihan guru tidak terbukti signifikan secara statistik.

\section{Kerangka Berpikir Kajian}

Sebelum guru mengikuti PLPG, guru harus mengikuti UKG terlebih dahulu. Guru kemudian diseleksi berdasarkan nilai UKG untuk mengikuti PLPG. Setelah mengikuti PLPG guru mengikuti UTN dan mendapat nilai UTN. Baik UKG maupun UTN, kedua tes ini mengetes tentang kompetensi pedagogik dan profesional. Rerata nilai UTN kemudian dibandingkan dengan rerata nilai UKG untuk menyimpulkan efektif tidaknya PLPG. Jika nilai rerata UTN > nilai rerata 
UKG dan perbedaannya secara statistik signifikan maka PLPG dianggap efektif namun jika perbedaannya tidak signifikan atau jika nilai rerata UTN < nilai rerata UKG maka PLPG dianggap tidak efektif. Selain itu dalam panduan pelaksanaan PLPG (KSG GTK Kemendikbud, 2013) ditetapkan standar kelulusan PLPG menggunakan Penilaian Acuan Patokan (PAP) yaitu untuk lulus PLPG nilai UTN harus minimal 42. Jadi jika nilai rata-rata $U T N \geq 42,0$ maka PLPG efektif, sebaliknya jika nilai rata-rata UTN < 42,0 maka PLPG tidak efektif.

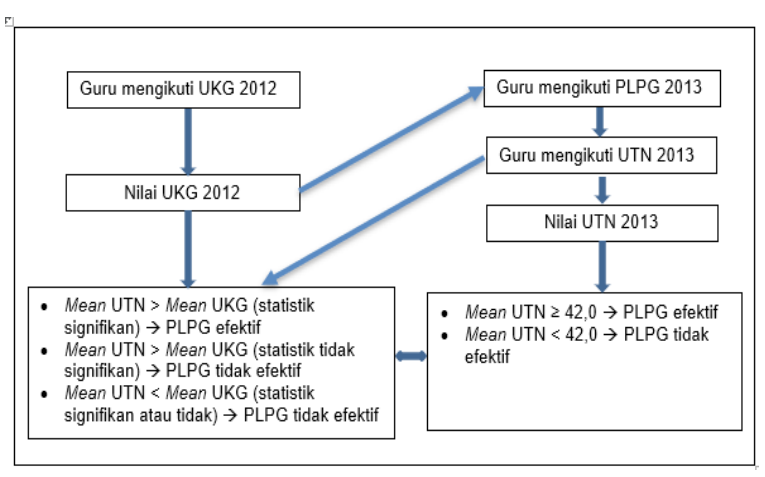

Gambar 3. Kerangka Berpikir Kajian

\section{Metode}

Pendekatan yang digunakan dalam kajian ini adalah kuantitatif. Populasi kajian ini adalah seluruh guru SD dan SMP yang mengikuti program sertifikasi dengan Pola PLPG pada tahun 2013. Studi ini tidak mengambil sampel secara khusus karena data dari seluruh peserta PLPG 2013 dianalisis untuk menyusun laporan kajian ini. Data yang digunakan dalam studi ini adalah data sekunder yang terdiri atas data kuantatif tentang nilai UKG 2012 dan nilai UTN peserta PLPG 2013 yang diperoleh dari Direktorat Jenderal Guru dan Tenaga Kepedidikan (Ditjen GTK Kemendikbud, 2013). Data kuantitatif ini diolah atau dianalisis menggunakan statistik inferensial dengan uji perbedaan mean (paired sample t-test).

Dari hasil analisis data nilai UKG dan UTN akan disimpulkan tentang efektif tidaknya PLPG. Jika mean UTN > mean UKG dan perbedaannya secara statistik signifikan maka PLPG dianggap efektif namun jika perbedaannya tidak signifikan maka PLPG dianggap kurang efektif. Selain itu jika ternyata mean $\mathrm{UTN}<$ mean UKG maka PLPG dianggap tidak efektif. Penilaian efektivitas PLPG juga dilakukan melalui Penilaian Acuan Patokan yaitu nilai UTN minimal 42,0. Jika rerata nilai UTN lebih besar dari 42,0 maka PLPG dianggap efektif, namun jika terjadi sebaliknya, maka PLPG dianggap tidak efektif.

\section{B. TEMUAN DAN PEMBAHASAN Kompetensi awal guru:}

Pada bagian ini dianalisis kompetensi guru sebelum mengikuti PLPG. Analisis yang dilakukan di sini dipisahkan antara guru berdasarkan satuan pendidikan tempat guru mengajar dan juga berdasarkan mata pelajaran yang diajarkan guru. Mengenai kompetensi awal, data yang dianalisis adalah data UKG 2012. Sebelum disajikan hasil analisis data tersebut, terlebih dahulu disajikan jumlah responden, agar diperoleh gambaran tentang jumlah responden kajian. Pada tahun 2013 jumlah guru yang direncanakan untuk mengikuti PLPG adalah seperti tertera dalam tabel berikut. Tabel menyajikan data paling mutakhir dari Ditjen GTK mengenai jumlah guru tahun 2012, jumlah guru yang sudah dan belum bersertifikat pendidik, jumlah guru yang belum berkualifikasi S-1/DIV dan data jumlah guru yang sudah dan akan disertifikasi sampai dengan 2014. 
Tabel 1 Data Guru pada Tahun 2012 yang Sudah dan Belum Disertifikasi

\begin{tabular}{clr}
\hline No. & \multicolumn{1}{c}{ Deskripsi Jumlah Guru } & Jumlah \\
\hline $\mathbf{1}$ & Total guru tahun 2012 & 2.925 .676 \\
\hline $\mathbf{2}$ & Jumlah Guru Tidak Tetap (GTT) dan guru PNS belum S1 & 831.163 \\
\hline $\mathbf{3}$ & Jumlah guru yang memenuhi syarat untuk disertifikasi & 2.094 .513 \\
\hline $\mathbf{4}$ & Jumlah guru yang memenuhi syarat yang diangkat sebelum 2005 & 1.716 .458 \\
\hline $\mathbf{5}$ & Jumlah guru memenuhi syarat yang diangkat setelah 2005 & 378.055 \\
\hline $\mathbf{6}$ & Total guru yang telah disertifikasi & 1.075 .497 \\
\hline $\mathbf{7}$ & Total guru yang belum disertifikasi (memenuhi syarat \& diangkat sebelum 2005) & 640.961 \\
\hline $\mathbf{8}$ & Kuota guru yang disertifikasi pada 2012 & 250.000 \\
\hline $\mathbf{9}$ & Rencana kuota sertifikasi pada 2013 & 250.000 \\
\hline $\mathbf{1 0}$ & Rencana kuota sertifikasi pada 2014 & 140.961 \\
\hline
\end{tabular}

Sumber: Ditjen GTK Kemendikbud, 2013

Dari tabel di atas terlihat bahwa quota guru yang sesuai rencana akan mengikuti sertifikasi pada tahun 2013 adalah sebanyak 250.000 guru yang berasal dari berbagai satuan pendidikan. Dalam tabel berikut disajikan jumlah responden yang dianalisis dalam kajian ini. Jumlah ini lebih kecil dari 250.000 orang guru karena dalam jumlah ini tidak termasuk guru TK, guru mata pelajaran di SD (guru Agama, guru Olahraga dan guru Mulok), guru SMA, SMK dan SLB.

Tabel 2 Jumlah responden kajian

\begin{tabular}{llrr}
\hline No & \multicolumn{1}{c}{ Jenis guru } & $\begin{array}{r}\text { Jumlah } \\
\text { responden } \\
\text { (orang) }\end{array}$ & $\begin{array}{c}\text { Jumlah } \\
\text { responden } \\
(\%)\end{array}$ \\
\hline 1 & Guru kelas SD & 154.269 & $84,7 \%$ \\
\hline 2 & Bahasa Indonesia SMP & 4.352 & $2,4 \%$ \\
\hline 3 & Bahasa Inggris SMP & 5.367 & $2,9 \%$ \\
\hline 4 & IPA SMP & 5.193 & $2,9 \%$ \\
\hline 5 & IPS SMP & 5.451 & $3,0 \%$ \\
\hline 6 & Matematika SMP & 4.812 & $2,6 \%$ \\
\hline 7 & PKn SMP & 2.668 & $1,5 \%$ \\
\hline Total & 182.112 & $100 \%$ \\
\hline
\end{tabular}

Dari tabel di atas terlihat bahwa jumlah guru kelas di SD yang menjadi responden dalam kajian ini sebanyak 154.269 orang atau mencapai 84,7 persen. Sisanya 15,3 persen guru SMP dengan jumlah terbanyak adalah guru IPS sebanyak 3,0 persen dan jumlah guru PKn adalah yang paling kecil yaitu hanya 1,5 persen. Dalam tabel berikut disajikan capaian UKG dari guru-guru ini berdasarkan satuan pendidikan.

Tabel 3 Nilai UKG Guru SD dan SMP

\begin{tabular}{lrr}
\hline \multirow{2}{*}{ Statistik } & \multicolumn{2}{c}{ Satuan Pendidikan } \\
\cline { 2 - 3 } & \multicolumn{1}{c}{ SD } & \multicolumn{1}{c}{ SMP } \\
\hline $\mathrm{N}$ & 154.269 & 35.060 \\
\hline Mean & 39,82 & 47,11 \\
\hline Median & 38,75 & 46,25 \\
\hline Standard Deviation & 12,25 & 14,80 \\
\hline Minimum & 0,00 & 0,00 \\
\hline Maximum & 100,00 & 96,25 \\
\hline
\end{tabular}

Sumber: Hasil olahan data UKG 2012

Dari tabel di atas terlihat bahwa capaian kompetensi guru SD maupun SMP masih rendah. Rerata nilai UKG masih di bawah standar minimal yang ditetapkan, yakni 70,0 (dalam skala 0-100), sebagaimana disampaikan Sampurno (2012). Lebih lanjut Sampurno menyampaikan bahwa rerata hasil UKG 2012 hanya sebesar 45,5, sehingga jauh di bawah Standar Kelulusan Minimal (SKM) yang dipatok pemerintah yaitu 70,0.

Terlihat dari tabel di atas bahwa ketika UKG 2012 dianalisis berdasarkan satuan pendidikan maka nilai UKG SMP adalah 47,11 lebih tinggi daripada SD 39,82. 
Selanjutnya dalam tabel berikut disajikan capaian UKG guru SMP berdasarkan mata pelajaran (Mapel) yang diampu guru.

Tabel 4 Rerata nilai UKG Guru SMP berdasarkan Mapel

\begin{tabular}{llccc}
\hline No & Jenis Mapel & $\mathrm{N}$ & $\begin{array}{c}\text { Rerata } \\
\text { nilai UKG }\end{array}$ & $\begin{array}{c}\text { Peringkat } \\
\text { capaian UKG }\end{array}$ \\
\hline 1 & $\begin{array}{l}\text { Bahasa } \\
\text { Indonesia }\end{array}$ & 4.352 & 59,0 & 1 \\
\hline 2 & $\begin{array}{l}\text { Bahasa } \\
\text { Inggris }\end{array}$ & 5.367 & 45,5 & 4 \\
\hline 3 & IPA & 5.193 & 48,9 & 2 \\
\hline 4 & IPS & 5.451 & 44,1 & 5 \\
\hline 5 & Matematika & 4.812 & 43,6 & 6 \\
\hline 6 & PKn & 2.668 & 47,0 & 3 \\
\hline
\end{tabular}

Sumber: Hasil olahan data UKG 2012

Dari tabel di atas terlihat bahwa capaian UKG guru Bahasa Indonesia adalah yang tertinggi di antara guru mata pelajaran di SMP. Capaian UKG terendah adalah guru Matematika. Meskipun demikian, capaian guru-guru tersebut sebagaimana diungkapkan sebelumnya masih lebih rendah daripada capaian minimum yang ditetapkan untuk UKG yaitu 70,0. Namun demikian, apapun hasilnya, hasil UKG ini tetap dijadikan sebagai syarat dalam mengikuti PLPG 2013.

\section{Kompetensi akhir guru:}

Yang dimaksud dengan kompetensi akhir guru adalah kompetensi yang dicapai guru setelah mengikuti PLPG. Kompetensi akhir ini diperoleh dari nilai UTN yang didapat oleh guru. Setelah guru mengikuti PLPG, guru mengikuti ujian tertulis yang dikenal dengan Ujian Tulis Nasional (UTN). Analisis yang dilakukan di sini dipisahkan antara guru berdasarkan satuan pendidikan tempat guru mengajar dan juga berdasarkan mata pelajaran yang diajarkan guru. Mengenai kompetensi akhir guru ini data yang dianalisis adalah data UTN.

Tabel 5 Nilai UTN Guru SD dan SMP

\begin{tabular}{lrr}
\hline \multirow{1}{*}{ Statistik } & \multicolumn{2}{c}{ Satuan Pendidikan } \\
\cline { 2 - 3 } & \multicolumn{1}{c}{ SD } & \multicolumn{1}{c}{ SMP } \\
\hline $\mathrm{N}$ & 154.269 & 35.060 \\
\hline Mean & 47,62 & 52,44 \\
\hline Median & 48,00 & 54,00 \\
\hline Standard Deviation & 14,22 & 17,99 \\
\hline Minimum & 0,00 & 0,00 \\
\hline Maximum & 99,00 & 97,50 \\
\hline
\end{tabular}

Sumber: Hasil olahan data UTN 2013

Dari tabel di atas terlihat bahwa capaian UTN guru SD maupun SMP juga masih rendah jika hasil yang dicapai ini dibandingkan dengan standar kelulusan yang ditetapkan untuk UKG yaitu minimal 70,0. Sama halnya dengan capaian UKG, terlihat bahwa rerata nilai UTN guru SMP juga sedikit lebih tinggi dari pada guru SD. Namun demikian, oleh karena standar kelulusan minimal PLPG yang ditetapkan untuk komponen UTN adalah minimal 42,0, maka untuk komponen ini sebagian besar guru dinyatakan melewati passing grade yang ditetapkan dan nilainya diproses lebih lanjut untuk menentukan kelulusan atau keberhasilan guru mengikuti PLPG, karena untuk bisa lulus PLPG guru harus lulus atas beberapa komponen penilaian sebagaimana yang disebutkan dalam kajian literatur. Selanjutnya dalam diagram berikut disajikan capaian UTN guru SMP per mata pelajaran (Mapel). Hal ini sengaja dilakukan untuk melihat capaian guru Mapel mana yang tertinggi dan capaian guru Mapel mana yang terendah, sehingga dapat dibandingkan dengan capaian guru ketika mengikuti UKG. 


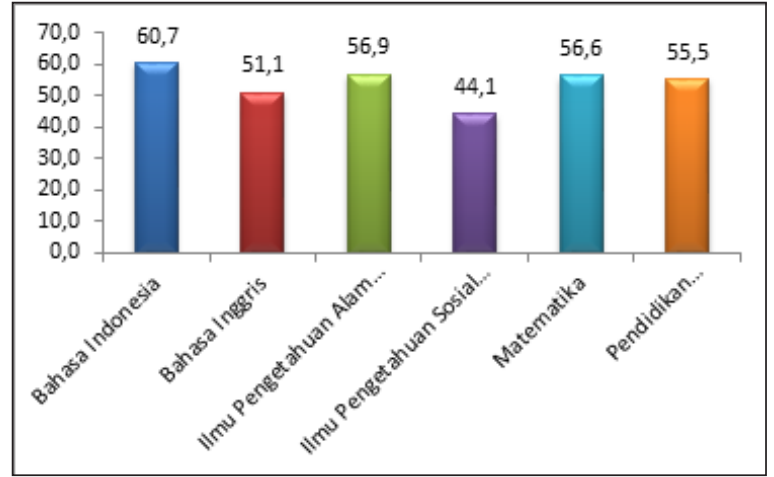

Gambar 4 Rerata nilai UTN Guru SMP per Mata Pelajaran

Sama seperti hasil UKG, dari diagram di atas terlihat juga bahwa capaian UTN guru Bahasa Indonesia adalah yang tertinggi di antara guru mata pelajaran lainnya di SMP. Namun demikian, capaian UTN per Mapel ini sedikit berbeda dengan hasil UKG. Jika untuk hasil UKG capaian guru Matematika adalah yang terendah, maka untuk hasil UTN, capaian terendah adalah oleh guru IPS. Capaian guru Matematika yang tadinya di posisi terbawah yaitu posisi keenam, kini meningkat ke posisi ketiga.

\section{Perbandingan Kompetensi Guru Sebelum dan Sesudah Mengikuti PLPG 2013:}

Tujuan ketiga dari kajian ini adalah menganalisis apakah terjadi peningkatan kompetensi guru setelah mengikuti PLPG. Sebelum guru diseleksi mengikuti PLPG guru tersebut harus mengikuti Uji Kompetensi Guru (UKG) terlebih dahulu. Berdasarkan nilai UKG 2013 tersebut guru diseleksi untuk mengikuti PLPG 2013.

Oleh karena rendahnya nilai $\mathrm{UKG}$, maka awalnya ditetapkan guru-guru yang boleh ikut PLPG adalah yang nilai UKG-nya minimal 30,0, sebagaimana disampaikan dalam panduan PLPG (KSG Kemendikbud, 2013). Namun demikian, kebijakan itupun berubah karena jumlah guru yang nilai UKGnya di atas 30,0 kurang dari kuota sertifikasi 2013 yaitu sebanyak 250.000 guru. Untuk memenuhi quota maka ada sebagian guru peserta PLPG 2013 nilai UKG-nya kurang dari 30,0.

Untuk membandingkan nilai UTN dan UKG perlu dicek terlebih dahulu apakah ada kesetaraan antara soal-soal UKG dan UTN. Untuk mengecek kesetaraan soal UKG dan UTN ini dilakukan pengecekan terhadap kisikisi soal UKG dan kisi-kisi soal UTN. Setelah dilakukan pengecekan dan perbandingan terhadap kisi-kisi soal untuk kedua jenis tes tersebut, ternyata kisi-kisinya sama sehingga kedua tes ini dianggap memiliki kesetaraan. Dengan demikian maka hasil kedua tes ini bisa dibandingkan. Sebelum dipaparkan perbandingan hasil kedua tes perlu diingatkan lagi bahwa tes ini mengukur kompetensi pedagogik dan profesional saja; dengan demikian, maka kompetensi yang dibandingkan di sini adalah hanya kedua kompetensi tersebut.

\section{Perbandingan rerata kompetensi guru kelas di SD:}

Perbedaan nilai UKG (kompetensi guru sebelum mengikuti PLPG) dan nilai UTN (kompetensi guru setelah mengikuti PLPG) pada guru SD disajikan dalam tabel berikut.

Tabel 6 Hasil Uji Perbedaan Rata-Rata Kompetensi Guru SD Sebelum dan Sesudah Mengikuti PLPG

\begin{tabular}{lcccccc}
\hline $\begin{array}{l}\text { Jenis } \\
\text { Tes }\end{array}$ & $\mathrm{n}$ & Mean & $\begin{array}{c}\text { St. } \\
\text { Dev }\end{array}$ & df & t-Stat & Sig. \\
\cline { 1 - 3 } UKG & 154.269 & 39,82 & 12,25 & 308.536 & $-163,19$ & 0,000 \\
\cline { 1 - 3 } & UTH.269 & 47,62 & 14,22 & & & \\
\hline
\end{tabular}

Sumber: Hasil olahan data UKG 2012 dan UTN 2013 
Pada tabel di atas terlihat nilai UKG SD lebih rendah daripada nilai UTN SD, ini bermakna adanya PLPG memberi dampak terhadap peningkatan kompetensi guru. Peningkatan nilai kompetensi guru sebelum dan sesudah mengikuti PLPG menunjukkan peningkatan yang signifikan. Hal ini terlihat dari hasil uji perbedaan rata-rata (paired sample t-test). Dari tabel di atas terlihat bahwa terjadi peningkatan kompetensi sebesar 7,80 poin $(47,62$ 39,82) dengan tingkat signifikansi kurang dari 0,05 (Sig. 0,000). Ini semua bermakna bahwa pada taraf signifikansi kurang dari 0,05 terjadi perbedaan cukup tinggi antara nilai kompetensi guru SD sebelum PLPG (nilai UKG) dan sesudah PLPG (nilai UTN). Atau dengan kata lain PLPG telah berhasil meningkatkan kompetensi pedagogik dan profesional guru SD.

Perbandingan Rerata Kompetensi Guru Mapel di SMP:

Tabel berikut menyajikan perbedaan nilai UKG dan UTN guru SMP. Guru SMP di sini terdiri atas guru yang mengajar mata pelajaran (i) Bahasa Indonesia, (ii) Bahasa Inggris, (iii) IPA, (iv) IPS, (v) Matematika dan (vi) PKn.

Tabel 7 Hasil Uji Perbedaan Rerata Kompetensi Guru SMP Sebelum dan Sesudah Mengikuti PLPG.

\begin{tabular}{ccccccc}
\hline $\begin{array}{c}\text { Hasil } \\
\text { Tes }\end{array}$ & $\mathrm{n}$ & Mean & St. Dev & df & t-Stat & Sig. \\
\cline { 1 - 4 } UKG & 35.060 & 47,11 & 14,80 & 70.118 & $-42,90$ & 0,000 \\
\cline { 1 - 3 } UTN & 35.060 & 52,44 & 17,99 & & & \\
\hline
\end{tabular}

Sumber: Hasil olahan data UKG 2012 dan UTN 2013

Pada tabel di atas terlihat nilai UKG SMP lebih rendah daripada nilai UTN SMP, ini bermakna adanya PLPG memberi dampak terhadap peningkatan kompetensi guru. Peningkatan nilai kompetensi guru sebelum dan sesudah mengikuti PLPG menunjukkan peningkatan yang signifikan. Hal ini terlihat dari hasil uji perbedaan rata-rata (paired sample t-test). Dari tabel di atas terlihat bahwa terjadi peningkatan kompetensi sebesar 5,33 poin $(52,44-47,11)$ dengan tingkat signifikansi kurang dari 0,05 (Sig. 0,000). Ini semua bermakna bahwa pada taraf signifikansi kurang dari 0,05 terjadi perbedaan cukup tinggi antara nilai kompetensi guru SMP sebelum PLPG (nilai UKG) dan sesudah PLPG (nilai UTN). Atau dengan kata lain PLPG telah berhasil meningkatkan kompetensi pedagogik dan profesional guru SMP. Untuk mengetahui apakah perbedaan nilai UTN dan UKG signifikan antar mata pelajaran maka dilakukan uji beda rerata nilai UTN dan UKG untuk setiap mata pelajaran.

Berikut disajikan tabel hasil uji beda rerata UTN dan UKG untuk setiap mata pelajaran di SMP.

Tabel 8 Hasil Uji Perbedaan Rerata Kompetensi Guru SMP per Mapel Sebelum dan Sesudah Mengikuti PLPG

\begin{tabular}{lcccc}
\hline \multicolumn{1}{c}{ Jenis Mapel } & n & Perbedaan rerata & t-statistik & Sig \\
\hline Bahasa Indonesia & 4.352 & 1,7 & 6,4 & 0,00 \\
\hline Bahasa Inggris & 5.367 & 5,6 & 25,6 & 0,00 \\
\hline IPA & 5.196 & 8,0 & 37,4 & 0,00 \\
\hline IPS & 5.451 & $-0,4$ & $-0,24$ & 0,81 \\
\hline Matematika & 4.812 & 12,9 & 51,7 & 0,00 \\
\hline PKn & 2.668 & 8,5 & 26,9 & 0,00 \\
\hline
\end{tabular}

Sumber: Hasil olahan data UKG 2012 dan UTN 2013

Dari tabel di atas, jika dirinci berdasarkan mata pelajaran, terlihat bahwa perbedaan UTN dan UKG signifikan untuk mata pelajaran Bahasa Indonesia, Bahasa Inggris, IPA, Matematika dan PKn, sedangkan untuk IPS perbedaannya tidak signifikan. Peningkatan kompetensi paling tinggi dicapai guru 
Matematika yaitu sebesar 12,9 poin, diikuti guru PKn di posisi kedua dengan 8,5 poin, kemudian di posisi ketiga guru IPA dengan peningkatan 8,0 poin. Pada posisi keempat ditempati guru Bahasa Inggris dengan peningkatan 5,6 poin kemudian di posisi kelima ditempati guru Bahasa Indonesia dengan peningkatan 1,7 poin. Untuk guru IPS justru terjadi sebaliknya yaitu tidak terjadi peningkatan. Yang terjadi justru penurunan kompetensi sebesar 0,4 poin. Hal ini tentunya menjadi perhatian khusus mengapa terjadi peningkatan kompetensi untuk guru Mapel lainnya sedang untuk Mapel IPS sendiri tidak terjadi peningkatan.

Untuk melihat efektivitas Diklat guru melalui PLPG juga diukur melalui capaian UTN oleh guru. Guru-guru baik SD maupun SMP, rerata UTN-nya seluruhnya lebih besar dari standar minimal kelulusan UTN yaitu minimal 42 sebagaimana yang disajikan dalam tabel berikut.

Tabel 9 Perbedaan nilai Capaian UTN dengan Standar Kelulusan UTN yang Ditetapkan yaitu $42,0)$

\begin{tabular}{|c|c|c|c|}
\hline Jenis Guru & $\begin{array}{c}\text { Rerata } \\
\text { UTN }\end{array}$ & $\begin{array}{c}\text { Perbedaan capaian UTN } \\
\text { dengan standar }\end{array}$ & $\begin{array}{l}\text { Peringkat perbedaan } \\
\text { UTN dan standar }\end{array}$ \\
\hline \multicolumn{4}{|l|}{ A. Guru SD: } \\
\hline - Guru kelas & 47,6 & 5,6 & 6 \\
\hline \multicolumn{4}{|l|}{ B. Guru SMP: } \\
\hline 1. Bahasa Indonesia & 60,7 & 18,7 & 1 \\
\hline 2. Bahasa Inggris & 51,1 & 9,1 & 5 \\
\hline 3. IPA & 56,9 & 14,9 & 2 \\
\hline 4. IPS & 44,1 & 2,1 & 7 \\
\hline 5. Matematika & 56,6 & 14,6 & 3 \\
\hline 6. PKn & 55,5 & 13,5 & 4 \\
\hline
\end{tabular}

Sumber: Hasil olahan data UKG 2012 dan UTN 2013

Dari tabel di atas terlihat bahwa perbedaan capaian UTN dengan standar kelulusan UTN yang ditetapkan (minimal 42,0) oleh guruguru seluruhnya lebih besar dari standar yang ditetapkan. Perbedaan paling besar dicapai guru Bahasa Indonesia SMP dengan 18,7 poin, diikuti guru IPA SMP di posisi kedua 14,9 poin, dan guru Matematika SMP di posisi ketiga dengan 14,6 poin. Setelah itu posisi keempat ditempati guru PKn SMP dengan 13,5 poin diikuti di posisi kelima oleh guru Bahasa Inggris dengan 9,1 poin. Posisi keenam ditempati guru kelas di SD dengan 5,6 poin, sedangkan posisi paling rendah ditempati guru IPS SMP dengan perbedaan hanya 2,1 poin. Dengan pengukuran ini PLPG untuk guru IPS masih cukup efektif namun ketika menggunakan pengukuran lainnya yaitu uji perbedaan mean antara UTN dan UKG ternyata PLPG tidak cukup efektif dalam meningkatkan kompetensi guru IPS SMP.

Jika dibadingkan hasil kajian ini dengan hasil kajian sejenis lainnya yang umumnya dilakukan pada tingkat yang lebih mikro sebagaimana disajikan pada kajian pustaka, maka hasil kajian ini pada tingkat makro ini hasilnya tidak berbeda jauh. Hasil kajian ini semakin memperkuat, mempertegas dan memperjelas simpulan bahwa pendidikan dan pelatihan guru termasuk PLPG memberikan dampak positif pada peningkatan profesionalisme guru terbukti dari hasil analisis data yang menunjukkan terjadi peningkatan kompetensi guru setelah mengikuti PLPG.

Berikut dirangkum dan disajikan dalam bentuk histogram tentang kompetensi guru sebelum dan sesudah mengikuti program PLPG, baik guru SD maupun guru SMP. Terlihat ada peningkatan kompetensi, yang mana peningkatan tersebut signifikan berdasarkan uji statistik perbedaan mean yang dilakukan sebagaimana ditunjukkan dalam tabel di atas. 


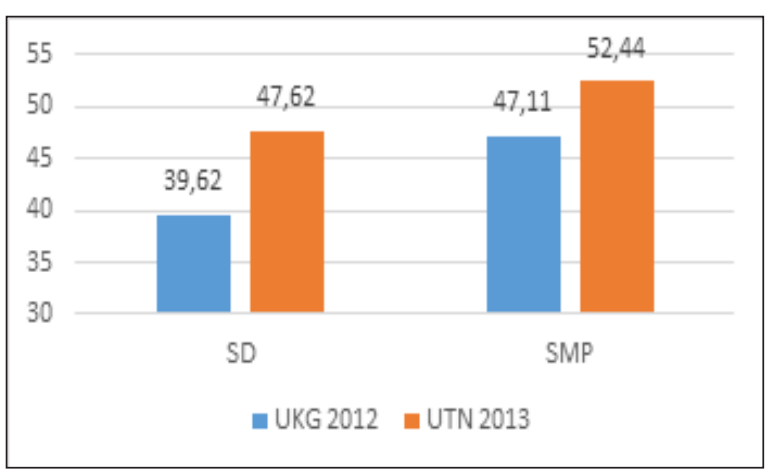

Gambar 5 Kompetensi guru sebelum dan sesudah mengikuti PLPG

\section{SIMPULAN DAN SARAN}

\section{Simpulan}

Capaian guru dalam Ujian Kompetensi Guru (UKG) tahun 2013 sangat tidak memuaskan karena rerata nilai UKG yang diperoleh guru lebih rendah daripada standar kelulusan minimal yang ditetapkan oleh pemerintah yaitu 70,0. Hasil kalkulasi menunjukkan bahwa rerata nilai UKG guru SD hanya 39,82 sedangkan rerata nilai UKG SMP adalah 47,11, jauh dari standar yang ditetapkan. Terlihat bahwa capaian guru SMP sedikit lebih baik daripada guru SD. Capaian UKG guru SMP ketika dikelompokkan berdasarkan mata pelajaran yang diampu juga masih lebih tinggi daripada guru SD. Capaian guru Bahasa Indonesia adalah yang tertinggi yaitu 59,0 diikuti guru IPA di peringkat kedua dengan 48,9, selanjutnya guru PKn di posisi ketiga dengan 47,0. Posisi keempat ditempati guru Bahasa Inggris dengan 45,5, kemudian posisi kelima ditempati guru IPS dengan 44,3. Posisi paling rendah dicapai guru Matematika yaitu dengan nilai 43,6. Meskipun rerata nilainya lebih rendah dari standar yang ditetapkan namun hasil UKG ini tetap dijadikan sebagai prasyarat dalam mengikuti PLPG, karena UKG merupakan alat untuk melakukan pemetaan terhadap kompetensi guru .

Salah satu komponen capaian guru setelah mengikuti PLPG adalah UTN. Dengan mengacu pada standar kelulusan UKG yang ditetapkan oleh pemerintah yaitu minimal 70,0, maka hasil UTN tahun 2013 juga tidak memuaskan karena rerata nilai UTN yang dicapai guru juga lebih rendah daripada standar kelulusan minimal tersebut. Hasil kalkulasi menunjukkan bahwa rerata nilai UTN guru SD hanya 47,62 sedangkan rerata nilai UTN guru SMP adalah 52,44. Sama seperti capaian guru untuk UKG, capaian guru SMP untuk UTN juga sedikit lebih baik daripada capaian guru SD. Capaian UTN guru SMP ketika dikelompokkan berdasarkan mata pelajaran yang diampu, capaian UTN untuk hampir semua guru Mapel masih lebih tinggi daripada guru SD. Capaian guru Bahasa Indonesia adalah yang tertinggi yaitu 60,7 diikuti guru IPA di peringkat kedua dengan 56,9 , selanjutnya guru Matematika di posisi ketiga dengan 56,6. Posisi keempat ditempati guru PKn dengan 55,5, kemudian posisi kelima ditempati guru Bahasa Inggris dengan 51,1. Posisi paling rendah dicapai guru IPS yaitu dengan nilai 44,1. Dari capaian ini terlihat bahwa capaian guru IPS SMP justru lebih rendah dari rerata UTN capaian guru SD. Namun demikian karena standar UTN yang diterapkan untuk kelulusan PLPG adalah minimal 42,0, maka capaian UTN guru-guru baik SD maupun SMP sudah cukup memadai untuk diproses lebih lanjut guna menetapkan kelulusan/keberhasilan guru atas Diklat guru melalui PLPG.

Dari hasil analisis data terlihat bahwa Diklat guru melalui PLPG secara efektif telah dapat meningkatkan kompetensi guru. Hasil uji statistik perbedaan mean UTN dan 
UKG (paired sample t-test) membuktikan demikian. Kesimpulan ini berlaku baik untuk guru SD maupun untuk guru SMP. Hanya saja ketika analisis untuk guru SMP dibedakan per mata pelajaran diperoleh hasil yang sedikit berbeda. Kesimpulan bahwa PLPG telah berhasil meningkatkan kompetensi pedagogik dan profesional guru hanya berlaku untuk guru Bahasa Indonesia, IPA, Matematika, Bahasa Inggris dan PKn, namun tidak berlaku untuk guru IPS. Hal ini karena perbedaan rerata UTN dan UKG guru IPS secara statistik tidak berbeda secara signifikan. Sebenarnya tanpa uji statistik pun perbedaannya sudah terlihat tidak signifikan karena rerata nilai UTN guru IPS justru sedikit lebih rendah daripada rerata nilai UKG guru IPS. Urutan efektivitas Diklat guru melalui PLPG mulai dari yang paling efektif sampai kepada tidak efektif: peringkat pertama guru Bahasa Indonesia SMP, peringkat kedua guru IPA SMP, peringkat ketiga guru Matematika SMP, peringkat keempat guru PKn SMP, peringkat kelima guru Bahasa Inggris SMP dan peringkat keenam adalah guru kelas SD. Khusus untuk guru IPS SMP PLPG ternyata tidak cukup efektif dalam meningkatkan kompetensi guru.

Bahwa efektivitas Diklat guru melalui PLPG cukup efektif juga didukung atau dipertegas oleh kenyataan bahwa rerata nilai UTN guru baik SD maupun SMP untuk seluruh mata pelajaran karena semuanya lebih besar dari standar minimal kelulusan UTN yang ditetapkan yaitu 42,0. Hanya saja dari sini terlihat bahwa pengukuran efektifivitas dengan cara ini kurang dapat dipercaya jika dibanding dengan pengukuran efektivitas menggunakan uji statistik perbedaan rerata (mean), karena dengan pengukuran terakhir ini ternyata untuk guru IPS SMP diperoleh kesimpulan bahwa PLPG tidak cukup efektif meningkatkan kompetensi guru.

Dengan adanya simpulan umum bahwa PLPG cukup efektif dalam meningkatkan kompetensi guru ini maka simpulan ini dapat menepis temuan yang diutarakan pada bagian latar belakang kajian yang menyatakan bahwa pelatihan guru yang selama ini dilaksanakan melalui berbagai proyek peningkatan mutu pendidikan banyak yang tidak efektif, karena banyak pelatihan dilaksanakan hanya sekedar untuk memenuhi tuntutan proyek, artinya PLPG tidak termasuk dalam salah satu dari proyek yang dimaksud.

\section{Saran}

Perlu dicarikan alternatif pelatihan guru yang berbiaya murah untuk melatih guru-guru karena kajian ini dan kajian sejenis lainnya menunjukkan bahwa Diklat guru terbukti efektif dalam meningkatkan kompetensi guru. Diklat yang berbiaya murah adalah belajar dari teman sejawat melalui $\mathrm{KKG} /$ MGMP. Untuk itu perlu diaktifkan kembali kegiatan belajar dari teman sejawat melalui KKG/MGMP.

Hasil UKG-2012 dan UTN-2013 ternyata sangat tidak memuaskan. Rerata nilai yang dicapai guru masih lebih rendah mengacu pada standar kelulusan minimal yang ditetapkan khusus untuk UKG yaitu minimal 70,0 dalam skala 1-100. Temuan ini berimplikasi pada pemerintah untuk menyiapkan anggaran untuk mengadakan pelatihan guna meningkatkan kompetensi guru agar menjadi lebih profesional. Jika hanya didasarkan pada nilai UKG maka perhatian khusus diarahkan kepada peningkatan kompetensi guru kelas di SD dan guru Matematika SMP karena 
rerata nilai UKG guru-guru kelompok ini yang paling rendah. Jika hanya didasarkan pada nilai UTN maka perhatian khusus lagilagi juga diarahkan kepada peningkatan kompetensi guru kelas di SD; namun untuk SMP perhatian khusus untuk guru IPS karena rerata nilai UTN guru-guru ini yang paling rendah. Cara yang dapat ditempuh: (i) bisa dengan mengaktifkan guru-guru mengikuti kegiatan $\mathrm{KKG} / \mathrm{MGMP}$ baik internal maupun eksternal sekolah. KKG internal: guru yang mengajar di SD yang memiliki kelas paralel dapat membentuk KKG internal dan mengadakan pertemuan rutin agar bisa saling belajar. Demikian pula halnya dengan MGMP internal: guru yang mengajar Mapel yang sama di suatu SMP dapat membentuk MGMP internal dan mengadakan pertemuan rutin untuk saling belajar. KKG/MGMP ekternal juga merupakan wadah tempat guru-guru belajar dari teman sejawat, dengan lingkup yang lebih luas karena merupakan kelompok guru yang mengajar mata pelajaran yang sama dari beberapa sekolah, jadi lingkupnya bisa kecamatan atau kabupaten/kota. Jika kegiatan KKG/MGMP selama ini sudah aktif maka terus ditingkatkan, namun jika kegiatannya sudah lama tidak aktif maka perlu diaktifkan lagi.

Untuk itu pemerintah dalam hal ini Dinas Pendidikan dan Ditjen GTK agar memberikan bantuan dana untuk memicu pengaktifan kembali KKG/MGMP yang tadinya tidak aktif, atau membentuk KKG/ MGMP baru yang tadinya belum ada; (ii) perlu ditumbuhkan budaya malu bagi guru yang kompetensinya rendah. Kepala sekolah, Dinas Pendidikan kabupaten/kota dan Ditjen GTK dalam berbagai kesempatan perlu menanamkan budaya malu bagi guru dengan memberitahu bahwa guru harus merasa tertantang bila mendapat TPG namun tidak dibarengi dengan peningkatan kompetensi. Sebagaimana diketahui, peserta PLPG kelak akan menerima Tunjangan Profesi Guru (TPG) karena PLPG memang arahnya selain untuk meningkatkan profesionalitas guru, juga untuk meningkatkan kesejahteraan/ penghasilan guru, maka kepada guru yang sudah menerima TPG sebaiknya dihimbau untuk memanfaatkan sebagian dari TPGnya untuk meningkatkan kompetensinya, misalnya dengan membeli buku pegangan guru, membeli laptop/komputer dan berlangganan internet untuk meng-update pengetahuannya dalam berbagai bidang khususnya terkait mata pelajaran yang diampunya.

Selanjutnya dengan pengecualian untuk guru IPS SMP, temuan umum kajian ini menunjukkan bahwa Diklat guru seperti PLPG cukup efektif dalam meningkatkan kompetensi profesional dan pedagogik guru. Untuk itu Diklat serupa perlu terus diadakan. Namun demikian, Diklat semacam itu berbiaya sangat besar, sehingga disarankan agar hanya diadakan khusus bagi peserta dengan seleksi yang ketat dan diwajibkan agar peserta yang sudah dilatih dapat menjadi instruktur pada KKG/MGMP baik internal maupun eksternal sekolah. 


\section{PUSTAKA ACUAN}

Chairiah, S. 2010. Efektivitas Pendidikan Dan Latihan Profesi Guru (PLPG) Dalam Menunjang Profesionalisme Guru (Studi Kasus pada Guru SMP Muhammadiyah 22 Setiabudi Pamulang Tangerang - Banten). Skripsi. Jakarta: Jurusan Ki-Manajemen Pendidikan Fakultas Ilmu Tarbiyah Dan Keguruan Universitas Islam Negeri UIN Syarif Hidayatullah Jakarta.

Detty, R., Christin dan Istiharini. 2008. Evaluasi Ke-Efektifan Program Pelatihan "Know Your Customer \& Money Laundering” Di Bank X Bandung. National Conference on Management Research 2008. Makassar, 27 November 2008.

Direktorat Jenderal Guru dan Tenaga Kependidikan (Ditjen GTK) Kementerian Pendidikan Dan Kebudayaan (Kemendikbud). 2013. Data peserta sertifikasi 2013, Data UKG 2012 dan Data UTN 2013.Jakarta, Kemendikbud

Konsorsium Sertifikasi Guru (KSG) Ditjen GTK Kemendikbud. 2013. Sertifikasi Guru Dalam Jabatan Tahun 2013, Panduan Pelaksanaan Pendidikan dan Latihan Profesi Guru (PLPG).

Ermawati, Lumban Toruan, J. dan Sudarman, Y. 2012. Penerapan Penilaian Beracuan Patokan Dan Beracuan Norma Pada Seni Musik Di SMP. E-Jurnal Seni Drama Tari dan Musik (Sendratasik) Program Studi Pendidikan Sendratasik Fakultas Bahasa dan Seni (FBS) Universitas Negeri Padang Volume 1, Nomor 1, September 2012, hlm. 52 - 59.

Gunarto. 2013. Teacher's Competence Examination (UKG). Jurnal Magistra Unwidha Klaten Volume XXV, Nomor 83, Maret 2013, hlm. 87-98.

Jalmo, T. dan Rustaman, N.Y. 2010. Pengembangan Program Pelatihan Peningkatan Kompetensi Guru IPA SMP. Jurnal Forum Kependidikan, Jurusan PMIPA FKIP Universitas Lampung dan Prodi IPA SPs Universitas Pendidikan Indonesia Volume 30, Nomor 1, Juni 2010, hlm. 79 - 88.

Kornelius, Margono, A. dan Hartutiningsih. 2014. Pendidikan Dan Pelatihan Guru Dalam Meningkatkan Kualitas Pendidikan Di SMP Negeri 27 Sendawar Kabupaten Kutai Barat Kalimantan Timur. eJournal Administrative Reform, Volume 2, Nomor 3, Tahun 2014, hlm. 1811-1823.

Lathifah, H. N. 2013. Pengaruh PLPG Terhadap Peningkatan Profesionalisme Guru PKn Di Kota Bandung. Skripsi. Bandung: Jurusan Pendidikan Kewarganegaraan Fakultas Pendidikan IPS, Universitas Pendidikan Indonesia.

Listiyani. 2014. Kontribusi Pelatihan Dan Pengalaman Mengajar Terhadap Profesionalisme Guru Sekolah Dasar Negeri Di Kecamatan Semin Kabupaten Gunung Kidul. Skripsi. Yogyakarta: Program Studi Pendidikan Guru Sekolah Dasar Jurusan Pendidikan Pra Sekolah Dan Sekolah Dasar Fakultas Ilmu Pendidikan Universitas Negeri Yogyakarta.

Martaningsih S.T. 2012. Analisis Ragam Kebijakan Pemerintah Dalam Pengembangan Profesionalitas Pendidik Dan Tenaga Kependidikan. Prosiding Seminar Nasional Pengembangan Pendidikan, Pengembangan Profesionalisme Pendidik dalam Menghasilkan Lulusan yang Berkompeten dan Berkarakter. Hotel Best Western Solo, 3 Nopember 2012, hlm. $249-264$ 
Meitaningrum, D.A., Hardjanto, I. dan Siswidiyanto. 2013. Efektivitas Pendidikan Dan Pelatihan Dalam Meningkatkan Kinerja Pegawai (Studi pada Badan Kepegawaian Daerah Kabupaten Malang). Jurnal Administrasi Publik (JAP) Jurusan Administrasi Publik, Fakultas Ilmu Administrasi, Universitas Brawijaya, Malang Volume 1, Nomor 3, Tahun 2013, hlm. 192-199.

Rezita, R. 2015. Pengaruh Pendidikan Dan Pelatihan (Diklat) Terhadap Kinerja Pegawai Pada Badan Perpustakaan dan Arsip Daerah Daerah Istimewa Yogyakarta (BPAD $D I Y)$. Skripsi. Yogyakarta: Program Studi Pendidikan Administrasi Perkantoran Jurusan Pendidikan Administrasi Fakultas Ekonomi Universitas Negeri Yogyakarta.

Rustiana, A. 2010. Efektivitas Pelatihan Bagi Peningkatan Kinerja Karyawan. Jurnal Dinamika Manajemen (JDM) Fakultas Ekonomi, Universitas Negeri Semarang Volume 1, Nomor 2, 2010, hlm. 137-143.

Sampurno, Y.G. 2012. Meraih Sukses Uji Kompetensi Guru Gelombang Pertama. Prosiding Seminar Nasional Peningkatan Kompetensi Guru dalam menghadapi UKG. Jurusan Pendidikan Teknik Boga dan Busana (PTBB) Fakultas Teknik (FT) Universitas Negeri Yogyakarta (UNY) Volume 7, Tahun 2012, hlm. 1-9.

Suharso, Y. 2013. Peran dan Tanggung Jawab Guru Sebagai Tenaga Profesional. Majalah Ilmiah Pawiyatan FPIPS IKIP Veteran Semarang Volume XX, Nomor 4, Oktober 2013, hlm. 112-123.

Syahbani, N. 2013. Profesionalisme Guru Dan Hasil Sertifikasi Guru Dalam Jabatan. Jurnal Al-'Ulum Volume 2, Tahun 2013, hlm. 84-94.

Syarif Hidayat, A. 2015. Pengaruh Pendidikan Dan Latihan Profesi Guru (PLPG) Dalam Menunjang Profesionalisme Guru IPS (Studi Kasus Pada Guru IPS SMP Se-Kecamatan Sawangan Depok Jawa Barat). Skripsi. Jakarta: Jurusan Pendidikan Ilmu Pengetahuan Sosial Fakultas Ilmu Tarbiyah Dan Keguruan Universitas Islam Negeri (UIN) Syarif Hidayatullah Jakarta

Pusat Penelitian Kebijakan Pendidikan dan kebudayaan Puslitjakdikbud. 2013. Evaluasi Dampak Peningkatan Kesejahteraan Guru Terhadap Mutu Input LPTK dan Dampak Pemberian Dana Insentif Akreditasi terhadap Mutu Lulusan LPTK. Laporan Penelitian. Pusat Penelitian Kebijakan Pendidikan dan Kebudayaan (Puslitjakdikbud) Badan Penelitian dan Pengembangan (Balitbang) Kementerian Pendidikan dan Kebudayaan

Undang-Undang Republik Indonesia Nomor 14 Tahun 2005 tentang Guru dan Dosen 